\title{
THE PROPERDIN SYSTEM AND IMMUNITY. IV. THE HEMOLYSIS OF ERYTHROCYTES FROM PATIENTS WITH PAROXYSMAL NOCTURNAL HEMOGLOBINURIA ${ }^{1}$
}

\author{
By CARL F. HINZ, JR.,2 WILLIAM S. JORDAN, JR., ANd LOLIS PILLEMER \\ (From the Department of Medicine, School of Medicine, and the Institute of Pathology, \\ Western Reserie University, Cleveland, $O$.)
}

(Submitted for publication November 14, 1955 ; accepted January 9, 1956)

Paroxysmal nocturnal hemoglobinuria (PNH) is a rare chronic hemolytic anemia characterized by an acquired defect of the erythrocyte which renders it susceptible to hemolysis by normal human serum. Previous reports have indicated that magnesium and factors resembling the components of complement are required for the hemolysis in vitro of $\mathrm{PNH}$ erythrocytes by normal serum $(1,2)$.

Recently a naturally occurring serum protein, properdin, has been described which requires magnesium and complement for its activity in vitro (3). Thus, properdin, magnesium, and complement have been termed the properdin system, which participates in the lysis of certain bacteria and the inhibition of certain viruses $(4,5)$.

The resemblance between the factors required for PNH hemolysis and the constituents of the properdin system prompted this study on the role of the properdin system in the hemolysis of PNH erythrocytes.

\section{METHODS}

The test system in all instances was the hemolysis of PNH erythrocytes obtained from three patients with typical PNH whose case histories will be reported elsewhere (6). The red blood cells from all three patients had similar characteristics.

Erythrocytes from oxalated or defibrinated blood were washed three times in isotonic sodium chloride and resuspended to a concentration of 50 per cent in isotonic sodium chloride containing $0.0005 \mathrm{M}$ magnesium chloride. They were stored at $4^{\circ} \mathrm{C}$ and discarded after 5 days.

Sera: Fresh, clotted venous blood was allowed to re-

1 Presented in part to the Central Society for Clinical Research, Chicago, Illinois, October 29, 1954. Supported in part by research grant No. H1263C from the National Heart Institute, National Institutes of Health, U. S. Public Health Service; and by a grant from Lederle Laboratories Division, American Cyanamid Company, Pearl River, New York.

2 U. S. Public Health Service Postdoctoral Research Fellow. main for 30 minutes at room temperature $\left(20^{\circ}\right.$ to $\left.25^{\circ} \mathrm{C}\right)$ and then stored overnight at $4^{\circ} \mathrm{C}$. Serum was separated from the clot by centrifugation and stored at $4^{\circ} \mathrm{C}$. On storage at $4^{\circ} \mathrm{C}$ serum loses its ability to hemolyze $\mathrm{PNH}$ erythrocytes in several days; therefore all sera were used within three days of collection. Serum, however, can be stored at $-70^{\circ} \mathrm{C}$ for at least six months without loss of hemolytic activity. Serum was diluted with isotonic sodium chloride containing $0.0005 \mathrm{M}$ magnesium chloride.

Heated serum was prepared by heating in a $56^{\circ} \mathrm{C}$ water bath for 30 minutes. Properdin is inactivated in such serum (3).

Hemolytic system: Except where indicated all tests were conducted in a buffered system at $\mathrm{pH} 6.8$ to 6.9 . Since minor variations in $\mathrm{pH}$ have been noted to result in marked changes in degree of hemolysis, a well buffered system is essential. The buffer was made by dissolving $3.4 \mathrm{gm}$. of imidazole in $90 \mathrm{ml}$. of $0.2 \mathrm{M}$ hydrochloric acid, and adding distilled water to $100 \mathrm{ml}$. This was titrated to $\mathrm{pH} 6.7$ with approximately 0.2 volumes of normal hydrochloric acid (7). All sera were acidified and buffered after heating or other pre-treatment. The addition of 0.1 volume of $0.145 \mathrm{M}$ hydrochloric acid and 0.1 volume of the buffer to one volume of serum, followed by 0.1 volume of the 50 per cent erythrocyte suspension resulted in a stable final $\mathrm{pH}$ of 6.8 to 6.9. The mixture was incubated for 15 minutes at $37^{\circ} \mathrm{C}$ in a water bath. After incubation and centrifugation, hemolysis was scored by inspection on a scale of 0 to +++ , or the free hemoglobin was determined quantitatively on an Evelyn photoelectric colorimeter to obtain per cent hemolysis. Changes in the number of transfused cells present in patient's cell population caused the variations in hemolysis observed in different experiments.

Special serum preparations: Serum samples from which components of complement, $C^{\prime} 1, C^{\prime} 2, C^{\prime} 3$, or $C^{\prime} 4$ had been removed, referred to respectively as $\mathrm{R} 1, \mathrm{R} 2, \mathrm{R} 3$, and $\mathrm{R} 4$, were prepared as previously described (8).

Properdin was removed from serum by exposing it to zymosan at $17^{\circ} \mathrm{C}(3)$. Serum rendered deficient of properdin by this means is called RP. It contains all measurable factors of the clotting system and all components of complement in amounts comparable to untreated serum. The RP used in these studies was required to meet the criteria previously established $(3,9)$.

Purified properdin was prepared by a method described elsewhere (3). It was concentrated to contain 100 to 700 units per $\mathrm{ml}$. in phosphate or barbital buffer and was diluted with isotonic sodium chloride immediately prior 
to use. Such preparations retained potency for at least 6 months at $-20^{\circ} \mathrm{C}$.

Resin-treated serum was prepared by the addition of an equal volume of Amberlite IRC-50 (sodium cycle) to serum for ten minutes at room temperature. In this way 99.9 per cent of calcium and magnesium ions were removed (10). Such serum was used immediately after preparation because of the instability of $C^{\prime} 1$ in the absence of calcium.

Thrombin: Lyophilized thrombin (Parke-Davis and Co.) was dissolved to a concentration of 1000 international units per $\mathrm{ml}$., in isotonic sodium chloride containing $0.0005 \mathrm{M}$ magnesium chloride. The solution was stored at $-20^{\circ} \mathrm{C}$ and thawed immediately prior to use. Fifty units $(0.05 \mathrm{ml}$.) was added to $1 \mathrm{ml}$. of serum in the PNH test system (11).

\section{RESULTS}

\section{Effect of removing properdin on $\mathrm{PNH}$ he- molysis}

The removal of properdin from serum rendered that serum inactive for the hemolysis of $\mathrm{PNH}$ erythrocytes (Table I). Fresh normal serum was found to be more hemolytic at $\mathrm{pH} 6.8$ than 7.4. At the optimum $\mathrm{pH}$ of 6.8 , serum from which properdin had been removed, (RP) was completely inactive for hemolysis of $\mathrm{PNH}$ cells, even though it contained normal amounts of all the components of complement. Other serum samples from which one component of complement had been removed, $R 1, R 2, R 3$, and $R 4$, were also inactive for $\mathrm{PNH}$ hemolysis, although $\mathrm{R} 2$ and $\mathrm{R} 4$ contained normal amounts of properdin.

However, as indicated in Table II, the removal of properdin from serum did not inactivate systems dependent on the action of a specific hemolysin, such as paroxysmal cold hemoglobinuria, anti-A or anti-B isohemolysin, amboceptor sheepcell hemolysin, or anti-human immune erythrocyte hemolysin. The hemolysis of $\mathrm{PNH}$ erythrocytes in a serum did not result in a decrease in the

TABLE I

The effect on hemolysis of $P N H$ erythrocytes of removing properdin from serum

\begin{tabular}{lcclc}
\hline \hline Serum & pH & Properdin & Complement & $\begin{array}{c}\text { Hemolysis } \\
\text { of PNH } \\
\text { erythrocytes }\end{array}$ \\
\hline Normal & 7.4 & Normal & Normal & + \\
Normal & 6.8 & Normal & Normal & +++ \\
RP & 6.8 & 0 & Normal & 0 \\
R1 & 6.8 & Normal & Lacks C'1 & 0 \\
R2 & 6.8 & Normal & Lacks C'2 & 0 \\
R3 & 6.8 & 0 & Lacks C'3 & 0 \\
R4 & 6.8 & Normal & Lacks C'4 & 0 \\
& & & &
\end{tabular}

TABLE II

The effects on PNH and immune hemolytic systems of removing properdin from serum

\begin{tabular}{|c|c|c|}
\hline Type of hemolysis & $\begin{array}{l}\text { Hemolysis } \\
\text { in whole } \\
\text { serum }\end{array}$ & $\begin{array}{c}\text { Hemolysis } \\
\text { in RP } \\
\text { serum }\end{array}$ \\
\hline $\begin{array}{l}\text { PNH } \\
\text { Paroxysmal cold hemoglobinuria } \\
\text { Anti-A, Anti-B } \\
\text { Sensitized sheep cell } \\
\text { Anti-human red cell } \\
\text { Hemolysin from patient with } \\
\text { acquired hemolytic anemia }\end{array}$ & $\begin{array}{l}\text { Present } \\
\text { Present } \\
\text { Present } \\
\text { Present } \\
\text { Present } \\
\text { Present }\end{array}$ & $\begin{array}{l}\text { Absent } \\
\text { Present } \\
\text { Present } \\
\text { Present } \\
\text { Present }\end{array}$ \\
\hline
\end{tabular}

level of complement or properdin in that serum. However, the assay methods would not detect small changes in either complement or properdin.

\section{Restoration of the ability to hemolyze PNH cells by the addition of purified properdin to $R P$ serum}

The addition of purified properdin to RP to a final concentration of 5 units per $\mathrm{ml}$. caused marked PNH hemolysis, whereas RP or properdin alone caused no hemolysis (Table III). Properdin prepared from cow or hog serum was also effective. Properdin did not restore hemolytic activity to R1, R2, R3, R4 and heated serum.

Comments: Removal of properdin from serum renders the serum inactive for hemolysis of $\mathrm{PNH}$ cells. No other measurable substance is removed, for such sera are essentially unchanged as regards complement and the clotting factors. The substance removed by zymosan behaves functionally as a single entity that is fully capable of restoring hemolytic power to RP. The failure of properdin to restore sera inactivated by other methods again

TABLE III

Restoration of ability to hemolyze PNH cells by the addition of properdin to $R P$ serum

\begin{tabular}{|c|c|c|}
\hline Serum & Added properdin & $\begin{array}{l}\text { Hemolysis } \\
\text { of PNH } \\
\text { erythrocytes }\end{array}$ \\
\hline $\begin{array}{c}\text { Normal } \\
\text { RP } \\
\text { RP } \\
\text { RP } \\
\text { RP } \\
\text { R1 } \\
\text { R2 } \\
\text { R3 } \\
\text { R4 } \\
\text { Heated } 56^{\circ} \mathrm{C} \\
\text { Isotonic sodium } \\
\text { chloride }\end{array}$ & $\begin{array}{l} \\
0 \\
5 \\
5 \text { units human } \\
5 \text { units hog } \\
5 \text { units cow } \\
5 \text { units human } \\
5 \text { units human } \\
5 \text { units human } \\
5 \text { units human } \\
5 \text { units human } \\
5 \text { units human }\end{array}$ & $\begin{array}{c}+++ \\
0 \\
+++ \\
+++ \\
+++ \\
0 \\
0 \\
0 \\
0 \\
0 \\
0\end{array}$ \\
\hline
\end{tabular}


demonstrates that other factors similar to or identical with the components of complement are essential for hemolysis of $\mathrm{PNH}$ cells. Although the inactivated sera were prepared by accepted methods, one cannot exclude the possibility that there are removed other unidentified substances unrelated to complement, but required for $\mathrm{PNH}$ hemolysis. The ability of properdin obtained from several animal species to restore the human $\mathrm{PNH}$ system strengthens the initial hypothesis that this factor is a common and basic constituent of serum.

\section{The requirement for magnesium in $P N H$ hemolysis}

Removal of magnesium and calcium from serum by cationic exchange resin rendered that serum inactive for hemolysis of $\mathrm{PNH}$ erythrocytes. Addition to resin-treated serum of calcium to a final concentration of $0.0015 \mathrm{M}$ did not restore the hemolytic property. Addition of magnesium in a concentration of $0.0005 \mathrm{M}$ resulted in complete restoration of the hemolytic system. Excesses of magnesium resulted in inhibition of hemolysis, probably because of the significant increase in total ionic strength. Addition of $0.0015 \mathrm{M}$ calcium to $0.0005 \mathrm{M}$ magnesium did not result in an increase in hemolysis greater than that resulting from addition of magnesium alone.

Thus, as previously demonstrated (1), there is an absolute requirement for magnesium in the hemolysis of $\mathrm{PNH}$ erythrocytes.

\section{Relation of serum properdin level to the PNH hemolytic activity of serum}

The properdin content of human sera correlated with the hemolytic activity of those sera against PNH erythrocytes. In a typical experiment (Table IV) a normal serum No. 1 containing 4 to 8 units of properdin per $\mathrm{ml}$. caused hemolysis of 34 per cent of the test cells, while another normal serum No. 2 containing 1 to 2 units of properdin per ml. caused only 14 per cent hemolysis. RP alone failed to cause hemolysis, but the addition of 3 units of properdin per ml. gave 23 per cent and 5 units caused 36 per cent hemolysis. There was a relationship between properdin content and hemolytic activity in many untreated sera and on adding properdin to RP. However, some untreated sera failed to show good correlation be-
TABLE IV

The relation of serum properdin level to hemolysis of PNH erythrocyles

\begin{tabular}{ccc}
\hline Serum & $\begin{array}{c}\text { Properdin } \\
\text { content }\end{array}$ & $\begin{array}{c}\text { Hemolysis } \\
\text { of PNH } \\
\text { erythrocytes }\end{array}$ \\
\hline units per ml. & per cent \\
Normal-No. 1 & $4-8$ & 33 \\
Normal-No. 2 & $1-2$ & 14 \\
RP & 0 & 0 \\
RP + 3 units properdin & 3 & 23 \\
RP +5 units properdin & 5 & 36 \\
\hline
\end{tabular}

tween properdin level and $\mathrm{PNH}$ activity. This inconsistency, presumably due to other limiting variables such as complement components, precludes the use of $\mathrm{PNH}$ hemolysis as a means of routine measurement of properdin in serum at this time.

\section{Relation of properdin to the thrombin effect on PNH hemolysis}

In normal serum with moderate hemolytic activity for $\mathrm{PNH}$ cells, addition of thrombin has been noted to result in increased hemolysis. This has been the basis of a diagnostic test for $\mathrm{PNH}$ (11), and forms an important part of a theory proposed by Crosby relating $\mathrm{PNH}$ hemolysis to the clotting system. Accordingly, the possible relationship between thrombin and properdin effect was investigated.

Both commercial and "pure" thrombin (ParkeDavis and Co.) were found to contain properdin activity, varying from one unit to four units of properdin in every 50 units of thrombin, which is the amount used in the thrombin test. Neither properdin nor thrombin was hemolytic alone, but the addition of equivalent amounts of thrombin or properdin to serum resulted in equal augmentation of hemolysis of PNH cells (Table V). Thus, a serum initially containing 2 units per $\mathrm{ml}$. of properdin caused 21 per cent hemolysis. Addition of 50 units of thrombin " $\mathrm{A}$ ", a preparation containing 2 units of properdin in each 50 units of thrombin, caused 45 per cent hemolysis; addition of 2 units of properdin resulted in 48 per cent hemolysis. On another occasion, using thrombin " $B$ ", a preparation containing approximately 4 units of properdin in each 50 units of thrombin, addition of 50 units of thrombin caused increase in hemolysis in serum from 11 per cent to 54 per cent. Five units of properdin gave an increase in hemolysis from 11 per cent to 56 per cent. 
TABLE V

Effects on hemolysis of adding properdin and thrombin to serum

\begin{tabular}{|c|c|c|c|}
\hline Date & Thrombin & Serum mixture & $\begin{array}{l}\text { Hemol- } \\
\text { ysis of } \\
\text { PNH } \\
\text { eryth- } \\
\text { rocytes }\end{array}$ \\
\hline \multirow[t]{2}{*}{$9-25-54$} & Thrombin "A" & & percent \\
\hline & $\begin{array}{l}\text { (50 units con- } \\
\text { tains } 2 \text { units of } \\
\text { properdin) }\end{array}$ & $\begin{array}{l}\text { Serum } \\
\text { Serum }+50 \text { units thrombin } \\
\text { Serum }+2 \text { units properdin }\end{array}$ & $\begin{array}{l}21 \\
45 \\
48\end{array}$ \\
\hline \multirow[t]{2}{*}{$1-14-55$} & Thrombin "B" & & \\
\hline & $\begin{array}{l}\text { (50 units con- } \\
\text { tains } 4 \text { units of } \\
\text { properdin) }\end{array}$ & $\begin{array}{l}\text { Serum } \\
\text { Serum }+50 \text { units thrombin } \\
\text { Serum }+5 \text { units properdin } \\
\text { RP } \\
R P+50 \text { units thrombin } \\
R P+5 \text { units properdin } \\
R 3+50 \text { units thrombin } \\
R 3+5 \text { units thrombin }\end{array}$ & $\begin{array}{r}11 \\
54 \\
56 \\
0 \\
27 \\
24 \\
0 \\
0\end{array}$ \\
\hline
\end{tabular}

The addition of 50 units of thrombin " $\mathrm{B}$ " or 5 units of properdin to RP resulted in 27 per cent hemolysis, but neither caused hemolysis when added to R3 or heated serum.

Larger amounts of thrombin have an anticomplementary effect on serum and could not be tested.

Comments: The detection of properdin in thrombin preparations and the evidence that 1) the hemolytic property of thrombin corresponds to its properdin content, and 2) thrombin specifically restores an RP serum to hemolytic activity, suggest that properdin is the active principle responsible for the effect of thrombin. Accordingly. the activity of thrombin may be due to the addition of properdin contained in thrombin rather than to the inactivation of a proposed inhibitor by thrombin per se. The coexistence of properdin with thrombin in preparations of the latter is not surprising, for both are $\beta$-englobulins with similar iso-electric points. It was not possible to remove properdin from thrombin preparations with $z y-$ mosan because of the requirement for magnesium and the components of complement.

\section{DISCLSSION}

Both complement and the clotting system have been implicated in the hemolysis in vitro of $\mathrm{PNH}$ erythrocytes. Originally Ham and Dingle (2) showed that destruction of any component of complement resulted in loss of hemolytic activity of serum, and that addition of guinea pig comple- ment to normal serum caused increased hemolysis. However, serum complement did not appear to be depleted during the hemolysis of $\mathrm{PNH}$ cells, and subsequent studies indicated that the hemolytic activity of a serum could be destroyed without loss of conventional complement (12). Thus, complement alone did not appear to be responsible for hemolysis of $\mathrm{PNH}$ cells, although factors similar to complement appeared to be necessary for the hemolytic reaction.

Crosby and Dameshek (13) proposed that the $\mathrm{PNH}$ hemolytic factor was related to ac-globulin, but Harris, Jordan. Pillemer, and Desforges (1) clearly showed that ac-globulin was not essential for hemolysis of $\mathrm{PNH}$ cells. More recently, Crosby (14) has proposed a complex of four accelerators and inhibitors of the $\mathrm{PNH}$ system related to the clotting mechanism. This theory had its origin in the observed clinical tendency to thrombosis in patients with $\mathrm{PNH}$, and it is based in large part on the action of thrombin in causing augmentation of $\mathrm{PNH}$ hemolysis in vitro. None of the four proposed factors has been identified in support of this theory.

The current study offers evidence that the properdin system, a natural defense mechanism of human serum, is required for $\mathrm{PNH}$ hemolysis. In every manner tested the PNH system is comparable in requirements and behavior to the reactions of the properdin system with zymosan, bacteria and viruses. All these reactions require magnesium and factors indistinguishable from complement along with properdin, and all are dependent on a specific temperature and $\mathrm{pH}$.

These observations support the findings of Ham and Dingle (2) that factors resembling complement are necessary for the hemolytic reaction against $\mathrm{PNH}$ erythrocytes. The demonstration of the participation of properdin in $\mathrm{PNH}$ hemolysis and its relation to complement may explain the hitherto confusing observations that 1) there is no utilization of complement during hemolysis, and 2) hemolytic activity may disappear without depletion of total complement. That there are additional undescribed factors affecting hemolysis is entirely possible.

These studies may identify one factor of the complex proposed by Crosby, for it is probable that properdin is one of the heat labile factors of earlier authors and may be the heat labile acceler- 
ator of Crosby. Further, properdin activity is probably responsible for the effect observed when thrombin is added to serum. The existence of a heat stable inhibitor which is inactivated by thrombin was proposed on the evidence that augmented hemolysis resulted from addition of thrombin to serum and its subsequent removal by barium sulfate. Since properdin is present in thrombin preparations and is not removed by barium sulfate, the "thrombin effect" could well be due to the addition of properdin, a procedure which has been shown to augment $\mathrm{PNH}$ hemolysis. Properdin has no demonstrable relationship to the clotting system, as evidenced by the fact that properdin preparations contain no activity similar to the described clotting factors, and a serum or plasma from which properdin has been removed is normal for known clotting factors when compared to an untreated control (3).

Thus, these studies indicate that the properdin system, consisting of properdin, components indistinguishable from complement, and magnesium, is required for the hemolysis of $\mathrm{PNH}$ erythrocytes in vitro. The earlier observations on the role of the properdin system in bacterial destruction and virus neutralization $(4,5)$ and the requirement of properdin for hemolysis in vitro of $\mathrm{PNH}$ cells, suggest that hemolysis of $\mathrm{PNH}$ erythrocytes may be due to the interaction of properdin with the stroma of the intact erythrocytes. It has already been suggested that the final destruction of $\mathrm{PNH}$ cells is due to a proteolytic enzyme system (1), and the relation of properdin to such a system awaits further investigation.

\section{SUM MARY}

1. Similarities between the factors required for $\mathrm{PNH}$ hemolysis and the factors comprising the properdin system are pointed out.

2. Removal of properdin from serum renders the serum inactive for $\mathrm{PNH}$ hemolysis but not for immune hemolytic systems; readdition of properdin derived from several species restores $\mathrm{PNH}$ hemolytic activity to such serum.

3. A relationship exists between the $\mathrm{PNH}$ hemolytic activities and properdin titers of sera. The addition of properdin to weakly lytic sera also augments hemolysis.

4. The ability of thrombin to affect $\mathrm{PNH}$ hemolysis may be due to the presence of properdin in samples of thrombin.
5. The PNH hemolytic system of normal serum includes properdin, factors resembling the components of complement, and magnesium.

\section{REFERENCES}

1. Harris, J. W., Jordan, W. S., Pillemer, L., and Desforges, J. F., The enzymatic nature of the factor in normal serum which hemolyses the erythrocytes of paroxysmal nocturnal hemoglobinuria. J. Clin. Invest., 1951, 30, 646.

2. Ham, T. H., and Dingle, J. H., Studies on destruction of red blood cells. II. Chronic hemolytic anemia with paroxysmal nocturnal hemoglobinuria: certain immunological aspects of the hemolytic mechanism with special reference to serum complement. J. Clin. Invest., 1939, 18, 657.

3. Pillemer, L., Blum, L., Lepow, I. H., Ross, O. A., Todd, E. W., and Wardlaw, A. C., The properdin system and immunity: I. Demonstration and isolation of a new serum protein, properdin, and its role in immune phenomena. Science, 1954, 120, 279.

4. Wardlaw, A. C., Blum, L., and Pillemer, L., Bactericidal activity of the properdin system in human serum. Federation Proc., 1955, 14, 480.

5. Wedgewood, R. J., Ginsberg, H. S., Seibert, R. H., and Pillemer, L., The inactivation of Newcastle disease virus by the properdin system. Am. J. Dis. Child., In press.

6. Hinz, C. F., Jr., Weisman, R., Jr., and Hurley, T. H., In preparation.

7. Mertz, E. T., and Owen, C. A., Imidazole buffer: its use in blood clotting studies. Proc. Soc. Exper. Biol. \& Med., 1940, 43, 204.

8. Ecker, E. E., Pillemer, L., and Seifter, S., Immunochemical studies on human serum. I. Human complement and its components. J. Immunol., 1943, 47, 181.

9. Pillemer, L., Blum, L., Lepow, I. H., Wurz, L., and Todd, E. W., The properdin system and immunity. III. The zymosan assay of properdin. J. Exper. Med., 1956, 103, 1.

10. Lepow, I. H., Pillemer, L., and Ratnoff, O. D., The influence of calcium ions on the inactivation of human complement and its components by plasmin. J. Exper. Med., 1953, 98, 277.

11. Crosby, W. H., Paroxysmal nocturnal hemoglobinuria. A specific test for the disease based on the ability of thrombin to activate the hemolytic factor. Blood, 1950, 5, 843.

12. Wagley, P. F., and Hickey, M. D., Susceptibility of red cells and serum factor in the mechanism of hemolysis in paroxysmal nocturnal hemoglobinuria. J. Clin. Invest., 1948, 27, 559.

13. Crosby, W. H., and Dameshek, W., Paroxysmal nocturnal hemoglobinuria. The mechanism of hemolysis and its relation to the coagulation mechanism. Blood, 1950, 5, 822.

14. Crosby, W. H., Paroxysmal nocturnal hemoglobinuria. Plasma factors of the hemolytic system. Blood, $1953,8,444$. 